\title{
Meeting at the Edges: Spaces, Places and Grassroots Governance Activism in Delhi
}

\section{Martin Webb}

\section{(2) OpenEdition}

\section{Journals}

\section{Electronic version}

URL: http://journals.openedition.org/samaj/3677

DOI: $10.4000 /$ samaj.3677

ISSN: $1960-6060$

\section{Publisher}

Association pour la recherche sur l'Asie du Sud (ARAS)

\section{Electronic reference}

Martin Webb, « Meeting at the Edges: Spaces, Places and Grassroots Governance Activism in Delhi », South Asia Multidisciplinary Academic Journal [Online], 8 | 2013, Online since 19 December 2013, connection on 19 April 2019. URL : http://journals.openedition.org/samaj/3677 ; DOI : 10.4000/ samaj.3677

This text was automatically generated on 19 April 2019

\section{$\Theta \Theta \Theta \Theta$}

This work is licensed under a Creative Commons Attribution-NonCommercial-NoDerivatives 4.0 International License. 


\title{
Meeting at the Edges: Spaces, Places and Grassroots Governance Activism in Delhi
}

\author{
Martin Webb
}

1 In this article, I explore the ways in which grassroots Civil Society Organisations (CSOs) which aim to promote active citizenship and the oversight of the local state amongst Delhi residents negotiate urban space in their work. These are groups working as coalitions of activists from the upper and lower middle classes and the urban poor, focused on promoting transparency, accountability and social inclusivity, and working across class boundaries in the city in attempts to improve citizen participation in governance (Jenkins 2007, Webb 2012). The practice of the CSOs that I describe, through their focus on drawing the poor and marginalised of the city into the work of improving urban governance, engages with the spatial-political logics of exclusivity, exclusion and self-interest that are understood to characterise urban space and governance initiatives in India. In contrast to citizens' associations which are attached to particular classes, residential areas or business interests (Ghertner 2011, Srivastava 2009), they work through a style of pro-poor, non-party, voluntary political action at the 'grassroots' (Baviskar 2010: 134, Kamat 2002: 19, Kothari 1990: 402, Omvedt 1993: 190-191) which aims to produce a sense of shared citizenship (Holston \& Appadurai 1996: 192). I have written elsewhere about the limitations of this type of grassroots action and how it does not easily free itself from the enduring structures of space, class, and patron-client relations in the city (Webb 2012). Here, my ethnographic focus is on the locations across the city's zones of social exclusion and exclusivity in which these CSOs engage with the public, and the different possibilities of realising their aim of shared citizenship and social inclusion at these locations.

2 This discussion is grounded in anthropological understandings of the 'spatialisation' of urban environments, that is, the ways in which space in cities is socially produced, constructed, and transformed through historical, social and economic processes, and how 
these processes interact with the everyday practices and lived experiences of social actors (Low 1996). An ethnographic focus on spatialised power also requires that we think about 'place'. As Rodman points out, 'Places are not inert containers. They are politicised, culturally relative, historically specific, local and multiple constructions' (Rodman 1992: 641). By exploring the different places in the city in which activist CSOs work and also present their idea of shared citizenship to others, we can better understand the work that these organisations do and how the coalitions between classes found within CSOs function. Put simply, where CSOs work has a profound effect on how they work and who can do the work.

3 This article also interacts with recent research by development academics into citizen engagement and democratic deepening which has revealed how transnational agendas promoting good governance and rights have opened up new opportunities and mechanisms for citizen participation and state accountability (Gaventa \& McGee 2010). Scholars focusing on the emergence of a multiplicity of participatory 'spaces for change' within policy regimes linked to neoliberal governance and rights based approaches to development, have raised concerns about the elite capture of participatory processes, the lack of voice of marginalised actors and the reproduction of social cleavages in participatory spaces (Cornwall 2004, Cornwall \& Coelho 2007, Dupont in this volume, Gaventa 2006, Robins et al. 2008). The concern is that without taking these aspects into consideration the much vaunted possibilities of transformative action within 'civil society' cannot be assessed and claims for improved democratic participation are left unsubstantiated (Gaventa 2006: 25).

The 'spaces for change' produced within these governance and rights agendas appear in a multiplicity of guises, framings and locations. Amongst others, they may be the 'invited spaces' created by governments and international development actors which draw in 'civil society representatives', usually from the educated elites, to engage in policy making (Gaventa \& McGee 2010: 8, Vene Klasen et al. 2004: 5). They may be the facilitated neighbourhood or village meetings created in the process of participatory development practice (Mosse 1994, Pottier 1998: 208), or the carefully prepared jan sunwai (public hearing) in which public information and government spending are interrogated collectively (Dey \& Sampat 2005, Goetz \& Jenkins 2001). They may also be the office spaces and public meetings described later in this article in which CSOs engage with the public. In these terms, the rather loose application of the term 'space' is not particularly illuminating, appearing as it does to stand in for something we might also conceptualise as 'voice'. This is where a grounded ethnographic focus on place and location takes us beyond policy prescriptions about promoting civil society engagement in governance and starts to show how these initiatives actually play out.

5 It should be noted that these are not radical, revolutionary or autonomous counterhegemonic 'spaces' in which challenges to the legitimacy of the state or the organisation of capital are articulated (Graeber 2002, Nash 2005: 22, Shah \& Pettigrew 2012). Rather, they are sites through which the hegemony of the state is reproduced by actors with disparate interests. As Kamat (2002: 134) points out, when the idea of the state operates as an implicit construct in struggles, as in governance and rights activism, and thus organisational pedagogy produces the state as ideologically and discursively ideal, then CSO activism plays a role in the reproduction of capitalist relations and the modern bourgeois state. 
6 Research into participatory governance schemes in metropolitan India that emerged after the $74^{\text {th }}$ Constitutional Amendment Act of 1992 prompted the development of a new policy framework for urban local governance, has added weight to concerns about power relationships in governance initiatives and the social spaces in which they take place. Scholars focusing on schemes such as Bhagidari, the Delhi government's project to involve citizens' groups in urban governance have noted the domination of the scheme by representatives of middle class Residents Welfare Associations (RWAs). By promoting the idea of the new middle class consumer citizen as a key actor in local governance (Srivastava 2009), scholars argue that the scheme has allowed the 'elite capture' (Kundu 2011) and 'gentrification' (Ghertner 2011) of governance agendas and the spaces for change and participation created by them in Delhi (Harriss 2010, Tawa Lama-Rewal 2007). These findings have been reproduced in research on middle class associational action and urban governance from other Indian cities, including Mumbai (Anjaria 2009, Zérah 2007), Chennai, and Bangalore (Harriss 2006, 2007). Here it appears, reminding us of Chatterjee's argument (2004: 38-41) about civil and political society, that an urban governance model that privileges civil society action has produced an exclusive field in which middle class 'proper' citizens attempt to mitigate the effects of the patron-client relationships and vote bank politics through which the urban poor secure footholds in the city.

7 There is truth in these observations, even though recent research suggests that the representation of the Indian urban middle classes as an undifferentiated mass acting together through civil society is over schematised. As Kamath and Vijayabaskar (2009) in Bangalore, and Coelho and Venkat (2009) in Chennai have found, middle class associational life is comprised of a great many different organisations, often representing unauthorised housing developments and businesses, employing a range of strategies for interacting with the state, including street protest and the petitioning of representatives, and with little objective interest in promoting an urban governance model based on the concept of the legitimate, tax-paying, consumer citizen. In this article, whilst I support the finding that forms of social and political action are not reserved for specific social classes, I provide a counterpoint to the common narrative emerging from much of the work on urban associations and social action; that is the way in which associations are understood to be working from within specific areas, in the interests of particular groups of residents, identified by social or economic position.

8 Nonetheless, the social and spatial segregation of urban India is not in doubt (Dupont 2004). While activists seeking to promote inclusive urban citizenship may challenge social and spatial boundaries in the course of their work, they still have to work through the spatialisation of the city. I would argue that in order to produce or prefigure shared citizenship and enrol people from a wide range of social backgrounds, as active citizens concerned about governance, CSO activists must find places in which these configurations are a possibility. Like other groups seeking to engage with the public, hawkers perhaps, or the labourers and tradesmen hunting daily wage employment who squat with their tools near to major road intersections and markets for building materials, these groups must primarily locate themselves at the edges of, or in between, zones of social exclusion and exclusivity in order to do their work.

9 A spatially and socially segregated city characterised by these zones is also necessarily made up of edges and in-betweens. These are not non-places (Augé 1995), empty of relationships or significance, and they are not the margins from which some suggest counter hegemonic cultural practice and resistance might emerge (hooks 1991). Rather, 
they are places that people might more easily pass through or do business in without risking damage to their social standing or challenges to the legitimacy of their presence, and places in which people of disparate social classes might more easily experience, sense, or even attempt to practise membership of a broader public associated with the city, or by extension, the nation. To begin thinking about edges and in-betweens in the city, we must start by asking the question: the edges of what? And so I now turn to a discussion of the production of space in Delhi.

\section{The production of economic and moral space: exclusivity, exclusion and edge spaces in the city}

The social and spatial segregation of Delhi has emerged through a number of historical processes, including the inscription of colonial power and modern administration on the city (Legg 2006a, 2007, Waldrop 2004: 96), the inward migration prompted by the chaos of partition at independence (Datta 1986, Singh 2000, Dupont et al. 2000: 229-230, Krishna Menon 2000: 150), the redevelopments of the city aimed at urban 'improvement' (Legg 2006b) and as Radhika Govinda outlines in her introduction to this volume, the emergence of the Delhi Development Authority (DDA) as the body charged with implementing Delhi's 'master plans'. It is important to note that the development of the planned city caused the simultaneous growth of an unplanned city to house the workers needed for construction projects. Shanty towns grew in the marginal spaces left over from the Master Plans, along the sides of railway tracks and watercourses and on undeveloped land acquired by the DDA (Baviskar 2003: 91).

11 From the early 1990s, middle class RWAs in Delhi started to erect gates across colony entrances in attempts to control the flows of people and traffic moving through residential spaces. As has been well documented in cities worldwide, this 'gating' is a response to, on the one hand, a 'politics of fear' in which threatening others are put under surveillance while moving in residential spaces or excluded altogether, and on the other hand, to a 'politics of forgetting' in which exclusionary forms of new middle class citizenship based on consumption are used to reorder urban space (Fernandes 2004, also see Caldeira 1996, Grewal 2006, Low 2001). But at the same time the quality of middle class life in urban India depends on the presence of the urban poor within colonies providing domestic labour and other services, including, ironically, private security (see Gooptu 2013). Studies of labour relations within gated colonies in metropolitan India have shown how the development of exclusive residential spaces has included a re-assertion of both class and caste differences as middle class, higher caste residents employ poorer lower caste workers to carry out tasks linked to ritual status (Froystad 2003, Waldrop 2004). This reassertion of difference has contributed to the solidifying of a middle class civic and moral sense, intrinsically linking concepts of good governance, citizenship and property ownership to specific urban locales, and which associates lower classes and castes not just with ritual pollution in domestic spaces but also with the perceived corruption of national life by the rise of lower caste groups in the political and bureaucratic spheres (Fernandes 2004, Fernandes 2006, Jaffrelot 2003). The spatialisation of the city created by the new middle class assertion of exclusivity is further entrenched by the 'worlding' of Delhi (Roy \& Ong 2011). This project drives an urban development process focused on civic beautification and improvements to the quality of infrastructure, such as expressways, flyovers and shopping malls, that supports the mobility, consumption 
practices and increasingly 'global' lifestyles of India's new middle classes and elites (Baviskar 2011, Fernandes 2006, Fernandes \& Heller 2006, Fuller \& Narasimhan 2007, Gupta \& Ferguson 1992: 20).

The corollaries of the development of these exclusive gated spaces are the hidden slums that service them. The 2001 Census identified around 600,000 households living in recognised slums in the city (Shiva Kumar and Government of NCT of Delhi 2006: 47). Some are sites of industrial production with small home based workshops producing piece rate goods for the wholesale markets of old Delhi; others house workers in the service industries: domestic servants, rickshaw drivers, fruit and vegetable hawkers, stone masons and daily wage labourers (Mitra 2003: 49). A significant part of the slum population in the city belongs to the Scheduled Caste/Scheduled Tribe category (SC/ST) (Bijulal 2004, Jha et al. 2007: 238) and a large percentage of those living in slum areas are also likely to be migrants from outside the city (Kaur 2001: 212, 2006: 196).

13 To ground this discussion in my field, I will briefly describe the neighbourhood in which some of my informants live, and where a part of the activities of the CSO that they work for is carried out. Durga Camp is a neighbourhood of about 7000 people, one of the many slum areas that fit into the interstices of the sprawling middle class cityscape of suburban Delhi (Peck 2005: 2). It contains a mixture of religious and caste communities, and first came up in the early seventies as a few unauthorised kacca (wood and thatch) houses providing homes to construction labourers, and then as an accretion of more solid brick structures, many of which now have two storeys. In many ways, Durga Camp is an 'affluent slum' (Kaur 2001: 213-217). Households might own items such as air coolers, televisions or gas cookers and manage joint incomes of over 3000 rupees (about 56 US dollars). It also exists as a political entity in that it has its own 'welfare association', mirroring those of the middle class colonies around it, with officers and an elected leader/representative known as a Pradhan, of which more below.

The neighbourhood is long and narrow, its shape delineated by the depression it sits in. Hemmed in by the high perimeter walls of surrounding middle class developments, it is only accessible via a narrow entrance at either end, the larger of which is crowned by a government sign announcing in Devanagari script that this is 'JJ Cluster-Durga Camp'. It is not a space that can be entered accidentally. Inside, the neighbourhood is split by two longitudinal lanes connected at various points and becoming tunnels where dwellings on either side of the lane meet overhead. Like many slum areas, it has come up on land unusable by the developers of the housing around it (Verma 2002: 69). It is built along a nullah (stream), which like most of the small water courses in the city, has become an open drain, winding between and often under the houses.

15 The Camp is seen as a problem, not least by the local councillor who described it to me as a 'headache' and by local middle class RWA activists who see it as a source of 'nuisance', a health hazard and a threat to property values. These attitudes reflect a broader discourse deployed by planning agencies tasked with developing large scale infrastructure developments or projects to beautify and gentrify urban space, which make slums extremely vulnerable to demolition (Dupont 2008, 2011 and in this volume, Ghertner 2011, 2012, Mehra 2009). Other framings of the camp flow from its official status as a slum neighbourhood and thus an area deserving of welfare programmes provided by the local state and non-governmental organisations (NGOs) focused on service delivery. In these conceptualisations it is a bounded space characterised by deprivation, and a lack of sanitation, and thus suitable for development interventions. The framings of the camp 
that the residents themselves offer reflexively incorporate these discourses. In conversations with camp residents, they derived dignity from their knowledge that the camp is a tough place to live, and that they are essential to the life of the city around them. But they also showed concern that an outsider such as myself might consider people from the camp dirty or without shame. The question 'did you drink our water?' put to me as a challenge by one camp resident when they learned that I had recently made a visit there is telling in this respect. They were asking if I had been willing to share something of the place and themselves rather than just move through the space. While segregation in Delhi is more often directed downwards, that is, the poor are kept out of upper class spaces unless they have a job to do there; it is also the case that slum neighbourhoods such as Durga Camp have their own type of exclusivity. Narrow and hard to find entrances, complicated layouts and rough reputations all discourage outsiders from going inside. Entry may depend on invitations or prior arrangements, and an unescorted visit from an outsider is likely to be treated with suspicion or even hostility.

Thus, we can see that the socially and politically inscribed, and physically bounded spaces of middle class colonies and slum neighbourhoods are produced in material form, literally materialised, by the economic, social and technical requirements of the city. At the same time, they are socially constructed by multiple framings drawing on historical, political and moral understandings of their role in the life of the city. But despite the social fact of these spatialised inequalities, it is not enough to simply carve up the city into zones of exclusivity and exclusion. This would not sufficiently recognise the flows and mediated connections that characterise everyday life in Delhi, and would also deny the possibility of a political collectivity beyond the level of the neighbourhood. Just as colonies and slums are materialised by economic and social processes, so are the spaces and places that lie in between them, spaces and places through which people move and experience the city, however fleetingly, as shared. This is why CSOs such as the ones I describe below site themselves at the edges of, or in between, socially inscribed spaces, and it is to accounts of this that I will now turn.

\section{Working at the edges}

17 One afternoon in early July 2007, I had been visiting Durga camp with Anand, a grassroots CSO worker. We had been inside the camp to check the progress of work being carried out by the Municipal Corporation of Delhi (MCD) to clean out the nullah. At a gathering of Durga Camp residents held at the CSO's nearby meeting room on 4 July, there had been heated exchanges between camp residents as some accused others of throwing trash into the nullah, blocking it and causing it to overflow. After a request to the MCD by workers from the CSO, labourers had begun work, but refuse being pulled out of the nullah was piling up in the narrow lanes and not being removed quickly enough.

Anand, a man in his early 20s, grew up and still lives in Durga Camp. He was unusual in the camp because he had completed his education up to $12^{\text {th }}$ class and had then gone on to take a bachelor's degree at a Hindi medium college of Delhi University. He had been working for the CSO since its inception in 2003 and had taken on the role of the CSO's day to day contact within the camp when the group opened its first office space nearby.

19 Emerging from the camp onto the road running past the entrance, we encountered a Pradhan (community leader/broker) from Durga camp sitting with a group of men by the handcart from which he conducted his business as a fruit seller. He was a man in late 
middle age who had been identified to me by workers from the CSO as the phalvala Pradhan (fruit-seller Pradhan). The phalvala Pradhan's business, beyond the selling of fruit, was to act as a fixer and mediator between the slums residents, local bureaucrats and political representatives. Pradhans are people who have the power of dalaali (negotiation/ brokerage), through political connections, social respect or money power, and are able to arrange resources such as water or electricity connections or mediate with those able to help with accessing state entitlements (Sethi 2006). The post is unofficial and unpaid, so a Pradhan must make it earn. A Pradhan's identity is also ambivalent, working for the community as a respected leader and mediator, recognised as someone who can deliver votes to politicians at election times in return for favours, access and resources, but sometimes using threats or coercion in order to hold on to power. As informants in Durga Camp pointed out to me, in a city where slums are under constant threat of demolition, and slum dwellers are very aware of their vulnerability, a Pradhan may be able to maintain their position by convincing people that he is the only one who can negotiate the slum's survival (also see Jha et al. 2007).

The relationship between the CSO activists from Durga camp and the phalvala Pradhan was one of mutual distrust. The stated aim of the CSO is to encourage people from all social backgrounds, particularly the urban poor, to get involved in the governance of their local area by gaining legal knowledge and using transparency and accountability mechanisms, such as the Right to Information, to audit the working of the local state and its agencies. Beyond the focus on empowerment and active citizenship the day to day work of the CSO activists involves mediating with the local state and representatives, chasing up bureaucratic grievances, and helping often illiterate people to access publicly provided goods, such as welfare and education, by assisting them with paperwork. In particular, the work of the CSO community mobilisers, all of whom are slum residents, is to bring people out from their neighbourhoods and assist them in attending CSO meetings and appointments at government offices (see Webb 2013). These efforts to engage people in the 'communicative logic of governance' (Cody 2009: 347) through which they might become visible as concerned citizens are also directed at uncovering corruption and embezzlement in welfare systems targeted at the poor (see Webb 2012). In these respects, the activities of the CSO mirror the work of the Pradhan and directly affect his business and social standing. Tensions over this issue were particularly evident in the relationship between Anand and the Pradhan.

21 Two years earlier, there had been an election for the position of Pradhan in Durga Camp and Anand had entered the campaign. He had become a popular and trusted figure in the camp through his advocacy work with the CSO and, using the image of an open book as his election symbol to highlight his education, he had won the contest. He then left the CSO after it was decided within the CSO that his ambivalent position as Pradhan would affect his ability to work for people outside of Durga Camp. Anand was proud of his achievement. However, the role of Pradhan was unpaid and the loss of the CSO salary put him in an awkward position both financially and morally. After working for so long as an honest broker for those in the camp, how could he legitimately support himself as a Pradhan? Anand gave up the post and returned to the CSO, figuring that he could continue to do his work but also earn an income that would help him to support his family and avoid moral compromise. The phalvala Pradhan, who had come second in the election, had been Anand's replacement. 

barbed comments from the Pradhan to his male friends, within earshot of Anand, about the ability of someone like Anand to really get the MCD workers to clean the nullah properly. In the preceding days, men from the camp's welfare association, headed by the Pradhan, had been going around the camp asking for 50 rupees per household to pay for a contractor to get the nullah unblocked. At the CSO organised meeting on 4 July, people had argued about the efficacy of giving the Pradhan money to make the arrangements. One woman said that the Pradhan's men had told her never to come to them for help again if she did not pay. The CSO workers had assured people that it was the responsibility of the MCD to clean the nullah, and that they should not give any money and allow the CSO workers to get the MCD to act. Anand made it clear that he would not pay and other CSO workers from Durga camp supported him, saying that Anand had been the best Pradhan that the camp had had and that the phalvala Pradhan and his men would cheat those who had paid.

Two things are significant here. The first is the way in which this account of the roles that the Pradhan and Anand play for the residents in Durga Camp problematises overdrawn distinctions between a bourgeois civil society of proper and active citizens and the mediated political society of the urban poor. The boundary between civil society activist and local broker is blurred in everyday practice (Webb 2012 and 2013; also see Jeffrey 2010), and Anand's election as Pradhan shows that moral discourses about the value of honesty and education are prevalent in the marginalised spaces of the city. The second, and more significant here, is the location at the edge of the camp at which our meeting with the phalvalla Pradhan took place, and the comparison with the nearby position of the CSO meeting rooms. Sitting on a patch of waste ground at the camp entrance, at the edge of a wide street skirting an area of middle class DDA housing, the phalvala Pradhan can observe the movements of people and goods in and out of the camp and be available to those who require his intercession to arrange contacts inside and outside the camp. In this public place at the edge of the complicated and socially proscribed space of the camp, he is easy to find. His work of mediation depends, to a great extent, on his accessibility and ability to contact people quickly. The presence of mobile phones has facilitated this process but has not necessarily changed the location from which a figure like the Pradhan might work. Similarly, outside the camp, located up a tree shaded road running beside the DDA housing blocks and less than 500 metres from where the phalvala Pradhan sits, are the two meeting spaces used by the CSO. The first is a ground floor room in the forecourt of one of the blocks and easily visible and accessible from the street. Equipped with one or two chairs, a telephone and a mat to cover the concrete floor, this was the CSO's original office. The room had been in use as a weekly meeting space until residents in the block had complained about the noise. Now, the office was open during the day as a place to which people could come for help with bureaucratic problems. Usually, the office would be staffed by one or two part time CSO workers and residents of Durga Camp. Anand would often be there, but also spent a good deal of time travelling in the area on his motorbike, visiting government offices with the CSO's clients and staying in touch by mobile phone. As with the location of the phalvala Pradhan's handcart, the office acts as a visible and accessible place where people might come to seek help. It is neither hidden within a slum neighbourhood gali (lane) nor beyond the guarded gates of a middle class colony residence, as are many NGO offices in Delhi. It has a wide open door, allowing a view of the whole of the inside of the room and is in an open space which carries no social 
challenge. The office also acted as a point of connection between middle class residents of the DDA flats and the camp who would often ask the CSO workers at the office who lived in Durga Camp if they could arrange casual labour for them.

The CSO had also taken on a rented space close by for holding meetings. To reach it, you walk less than 100 metres across the road and up a side lane leading behind the DDA flats and into what was once one of Delhi's villages but which has since become a heavily built up area of small shops and lower middle class housing. The meeting room is in the basement of a house where the DDA development meets the edge of the village. It is a large rectangular space with two small rooms attached. I once counted fifty people gathered there, conducting discussions, sitting on mats on the floor (to demonstrate a lack of hierarchy), though regular attendance for meetings usually approached only half of this number. The room is easily accessible for those seeking out the CSO's weekly meeting, which is mostly attended by women from Durga Camp and other poor neighbourhoods close by; these women are encouraged by the CSO's female community mobilisers to attend the meeting. The location at the intersection of two different residential areas means that the meeting room is not far enough into the twisting lanes of the village to become enmeshed in the social life and specific class and caste identities of the area, and does not require women to move through areas where their safety and honour might be compromised.

This feature of siting office spaces very close to, but not within, the deprived areas that they worked with was repeated with other transparency and accountability activist CSOs in Delhi. On a visit to a CSO in another part of the city, I went for a walk with two activists into the slum neighbourhoods in which they focused part of their work. Again the CSO's office, an open fronted room with space to sit a few people on the floor, was located at the mouth of a lane which opened out into a busy area of shops and market stalls and on the edge of a tightly packed area of homes and small industrial workshops producing garments and jewellery for the giant wholesale market of Sadar Bazar in the old city. As with the CSO working in and around Durga Camp, the message in siting this CSO's office on the edge of this complicated area was clear. People wishing to access the CSO or participate in its work must come out of their neighbourhood and be willing to attempt to engage as active citizens. As one activist from this CSO said to a woman who had come demanding that the CSO help her obtain a voters card, 'Come on Tuesday with all your documents. I don't know whether your work will be done or not but I assure you that your work will never be done by sitting at home.' Another worker at this CSO highlighted how auto-rickshaw drivers familiar with the work of the group would often bring potential clients from other areas of the city to seek help with bureaucratic grievances. As is the case with the CSO working close to Durga Camp, if the office was in a space too closely identified with a particular constituency or set of class or caste identities, this would not be possible. Areas recognised as exclusive or excluded are not spaces in which the pre-figurative practice of the grassroots politics of shared and active citizenship can easily be worked through.

This becomes even clearer when we look at the outreach work of CSOs such as the ones I have introduced above. Activists also go behind the gates of Delhi's exclusive gated colonies to present their ideas about urban governance to RWAs of the affluent and well connected. The tension between the CSOs' attempts to foster shared citizenship and the spatial politics of the city is perhaps most evident in these gatherings. Observing upper middle class CSO leaders, high in social and cultural capital (Bourdieu 1986), make their 
pitch at RWA meetings within some of Delhi's most prestigious colonies, it was striking how the methods that they put forward for holding the government to account gained traction with audiences of elite property owning residents. By offering transparency mechanisms, such as the Right to Information, as a means of uncovering the local government corruption and malpractice, which colony residents blame for a plethora of local problems, the middle class CSO activists presenting, usually in English, could easily grab the attention of the audiences. The meetings would be oriented towards promoting shared citizenship, with CSO publicity films shown highlighting how these same mechanisms could help the urban poor secure rights to welfare and education. Narratives about holding the state to its promises of national development were relatively uncontroversial in these settings, appealing to the notional, and national, figure of the " aam admi' (common man) who suffers the vicissitudes of corruption, and providing a possible point of identification between the elites and the urban poor.

However, slum dwelling activists such as Anand would be less likely to present their stories at these elite RWA events. In the setting of an elite colony RWA meeting, reminders that these same mechanisms might offer a means to secure more permanent residence and legitimate claims of citizenship for the urban poor would be less well received. For these elite RWA members, narratives about the plight of the poor, albeit provided by well-meaning middle class CSO leaders, offer further examples of the nuisance, chaos and misery caused by a lack of governance in the city. They might not blame the poor for their position, and may see them as deserving of charity and employment as servants, but the very proximity of the urban poor is further evidence of the corruption of the local state (Visvanathan 2008). In this elite discourse the poor are still a 'problem' requiring a solution, such as resettlement, in order to improve the city (Ghertner 2011). As Appadurai points out, 'in all societies based on financial apartheid one wants the poor near at hand as servants but far away as humans' (Appadurai 2000: 637). Whilst mechanisms for transparency and accountability and strategies for their use may be well received in these zones of exclusivity, the politics of shared citizenship promoted by the CSOs gains little traction.

\section{The edges as spaces for change?}

In this article, I have introduced the work of CSOs in Delhi, which act as coalitions of the middle classes and urban poor who attempt to promote engagement with urban governance and shared citizenship across the social spectrum of the city. They do this by appealing to, and engaging with, dissatisfaction with the workings of the local state prevalent amongst all sections of society, and by promoting the use of transparency and accountability mechanisms to oversee public spending, and redress bureaucratic grievances. Through outreach work in the excluded and exclusive spaces of the city, they appeal to the interests of different social groups and persuade people to use transparency and accountability mechanisms for their own ends. The rub is that these mechanisms may be used just as well in a campaign by a middle class RWA seeking to remove an illegal slum from its vicinity as they might be by members of the urban poor in seeking ration entitlements or documentation that will help to secure legitimate residence in the city. emerging from the subaltern margins of the city, as people apparently act as 'insurgent citizens' (Holston 2009), claiming rights and participating in the reform of governance of 
the city, but using mechanisms that emerge from the implementation of new global regimes of transparency and accountability and participating in reproducing the hegemony of the state. We also interrogate assertions and assumptions about the 'civil' and the 'political' in society, while observing that where these ideas gain currency they have considerable power to structure relationships between elites and the urban poor, and to steer the course of local governance schemes such as Bhagidari. The shared citizenship that these activist CSOs seek to prefigure in their everyday practice does not play out so much in their outreach work, or even in the social composition of the CSOs themselves. They comprise members of the educated middle classes and the urban poor, but often have to work with the grain of inequality, rather than against it, by delegating particular tasks to those with the social and cultural capital most suited to carrying them out. The middle class members engage with the media, elite RWAs, legal English and policy analysis whereas the members from the urban poor mobilise the slum communities that they can most easily move within. Where the shared and active citizenship that these activists would prefigure is most in evidence is in the activist meeting rooms and offices located at the edges of the zones of exclusion and exclusivity. To attend these offices and meeting spaces, people must travel beyond the socially inscribed zones that they inhabit and sit down with disparate others to work upon the everyday practice of shared citizenship. This practice is made possible by locations that are accessible to a wide variety of people and present little social risk. Nonetheless, considering the enduring differences in life trajectories within the city and between activists from different social backgrounds, the politics of shared citizenship remains something that is processual and incomplete.

\section{BIBLIOGRAPHY}

Anjaria, Jonathan S. (2009) 'Guardians of the Bourgeois City: Citizenship, Public Space, and Middle-Class Activism in Mumbai', City \& Community, 8(4), pp. 391-406.

Appadurai, Arjun (2000) 'Spectral Housing and Urban Cleansing: Notes on Millennial Mumbai', Public Culture, 12(3), pp. 627-651.

Augé, Marc (1995) Non-places: Introduction to an Anthropology of Supermodernity, London: Verso.

Baviskar, Amita (2003) 'Between Violence and Desire: Space, Power, and Identity in the Making of Metropolitan Delhi', International Social Science Journal, 55(1), pp. 89-98.

Baviskar, Amita (2011) 'Cows, Cars and Rickshaws: Bourgeois Environmentalists and the Battle for Delhi's Streets', in Amita Baviskar \& Raka Ray (eds.), Elite and Everyman: The Cultural Politics of the Indian Middle Classes, New Delhi: Routledge, pp. 391-418.

Bijulal, M.V. (2004) City Slum and the Marginalised: Dalits and Muslims in Delhi Slums, New Delhi: Indian Social Institute.

Bourdieu, Pierre (1986) 'The Forms of Capital', in John G. Richardson (ed.), Handbook of Theory and Research for the Sociology of Education, New York: Greenwood Press, pp. 241-58. 
Caldeira, Teresa P. R. (1996) 'Fortified Enclaves: The New Urban Segregation', Public Culture, 8(2), pp. 303-28.

Chatterjee, Partha (2004) The Politics of the Governed: Reflections on Popular Politics in Most of the World, New Delhi: Permanent Black.

Cody, Francis (2009) 'Inscribing Subjects to Citizenship: Petitions, Literacy Activism, and the Performativity of Signature in Rural Tamil India', Cultural Anthropology, 24(3), pp. 347-80.

Coelho, Karen; Venkat, T. (2009) 'The Politics of Civil Society: Neighbourhood Associationism in Chennai', Economic and Political Weekly, 44(26/27), pp. 358-67.

Cornwall, Andrea (2004) 'Introduction: New Democratic Spaces? The Politics and Dynamics of Institutionalised Participation', IDS Bulletin, 35(2), pp. 1-10.

Cornwall, Andrea; Schatten Coelho, Vera (2007) Spaces for Change? The Politics of Citizen Participation in New Democratic Arenas, London: Zed Books.

Datta, V. N. (1986) 'Punjabi refugees and the Urban Development of Greater Delhi', in Robert E. Frykenberg (ed.), Delhi through the Ages: Selected Essays in Urban History, Culture and Society, New Delhi: Oxford University Press, pp. 287-305.

Delhi Development Authority (2006) Master Plan for Delhi, 1962, New Delhi: Akalank Publications. Dey, Nikhil; Sampat, Preeti (2005) 'Bare Acts and Collective Explorations: The MKSS Experience with the Right to Information', in Monica Narula, Shuddhabrata Sengupta, Jeebesh Bagchi \& Geert Lovink (eds.), Bare Acts, New Delhi: Sarai Media Lab, pp. 385-396.

Dupont, Véronique (2004) ‘Socio-spatial differentiation and residential segregation in Delhi: A Question of Scale?', Geoforum, 35(2), pp. 157-175.

Dupont, Véronique (2008) 'Slum Demolitions in Delhi since the 1990s: An Appraisal', Economic and Political Weekly, 43(28), pp. 79-87.

Dupont, Véronique (2011) 'Infrastructure Project, Beautification and Forced Evictions in Delhi: The Exemplary Story of a Cluster of Slum Dwellers Rendered Homeless', paper presented in the conference on Rethinking Development in an Age of Scarcity and Uncertainty: New Values, Voices and Alliances for Increased Resilience, University of York, 19-22/09/2011.

Dupont, Véronique; Tarlo, Emma; Vidal, Denis (eds.) (2000) Delhi: Urban Space and Human Destinies, New Delhi: Manohar Publishers \& Distributors.

Fernandes, Leela (2004) 'The Politics of Forgetting: Class Politics, State Power and the Restructuring of Urban Space in India', Urban Studies, 41(12), pp. 2415-30.

Fernandes, Leela (2006) India's New Middle Class: Democratic Politics in an Era of Economic Reform, Minneapolis: University of Minnesota Press.

Fernandes, Leela; Heller, Patrick (2006) 'Hegemonic Aspirations: New Middle Class Politics and India's Democracy in Comparative Perspective', Critical Asian Studies, 38(4), pp. 495-522.

Froystad, Kathinka (2003) 'Master-Servant Relations and the Domestic Reproduction of Caste in Northern India', Ethnos, 68(1), pp. 73-94.

Fuller, Christopher J.; Narasimhan; Haripriya (2007) 'Information Technology Professionals and the New-Rich Middle Class in Chennai (Madras)', Modern Asian Studies, 41(1), pp. 121-50.

Gaventa, John (2006) 'Finding the Spaces for Change: A Power Analysis', IDS Bulletin, 37(6), pp. 23-33. 
Gaventa, John and Rosemary McGee (eds.) (2010) Citizen Action and National Policy Reform: Making Change Happen, London: Zed Books.

Ghertner, D. Asher (2011) 'Rule by Aesthetics: World-Class City Making in Delhi', in Ananya Roy \& Aihwa Ong (eds.), Worlding Cities: Asian Experiments and the Art of Being Global, Oxford: Blackwell Publishing, pp. 279-306.

Ghertner, D. Asher (2012) 'Nuisance Talk and the Propriety of Property: Middle Class Discourses of a Slum-Free Delhi', Antipode, 44(4), pp. 1161-87.

Goetz, Anne Marie; Jenkins, Rob (2001) 'Hybrid Forms of Accountability: Citizen Engagement in Institutions of Public Oversight in India', Public Management Review, 3(3), pp. 363-83.

Gooptu, Nandini (2013) 'Servile Sentinels of the City: Private Security Guards, Organized Informality, and Labour in Interactive Services in Globalized India', International Review of Social History, 58(1), pp. 9-38.

Graeber, David (2002) 'The New Anarchists', New Left Review, 13, Jan/Feb, pp. 61-73.

Grewal, Inderpal (2006) 'Security Moms' in the Early Twentieth-Century United States: The Gender of Security in Neoliberalism', Women's Studies Quarterly, 34(1), pp. 25-39.

Gupta, Akhil (2005) 'Narrating the State of Corruption' in Dieter Haller \& Cris Shore (eds.), Corruption: Anthropological Perspectives, London: Pluto Press, pp. 172-93

Gupta, Akhil; Ferguson, James (1992) ‘Beyond 'Culture': Space, Identity, and the Politics of Difference', Cultural Anthropology, 7(1), pp. 6-23.

Harriss, John (2006) 'Middle-Class Activism and the Politics of the Informal Working Class: A Perspective on Class Relations and Civil Society in Indian Cities', Critical Asian Studies, 38(4), pp.445-65.

Harriss, John (2007) 'Antinomies of Empowerment: Observations on Civil Society, Politics and Urban Governance in India', Economic and Political Weekly, 42(26), pp. 2716-24.

Harriss, John (2010) “Participation' and Contestation in the Governance of Indian Cities', Simons Papers in Security and Development, 3, pp. 1-23.

Holston, James (2009) 'Insurgent Citizenship in an Era of Global Urban Peripheries’, City \& Society, 21(2), pp. 245-267.

Holston, James; Appadurai, Arjun (1996) ‘Cities and Citizenship', Public Culture, 8(2), pp. 187-204.

hooks, bell (1991) Yearning: Race, Gender, and Cultural Politics, Boston: Turnaround.

Jaffrelot, Christophe (2003) India's Silent Revolution: the Rise of the Lower Castes in North India, London: Hurst \& Co.

Jeffrey, Craig (2010) Timepass: Youth, Class, and the Politics of Waiting in India, Stanford: Stanford University Press.

Jenkins, Rob (2007) ‘Civil Society versus Corruption', Journal of Democracy, 18(2), pp. 55-69.

Jha, Saumitra; Rao, Vijayendra; Woolcock, Michael (2007) 'Governance in the Gullies: Democratic Responsiveness and Leadership in Delhi's Slums', World Development, 35(2), pp. 230-46.

Kamat, Sangeeta (2002) Development Hegemony: NGOs and the state in India, New Delhi: Oxford University Press.

Kamath, L.; Vijayabaskar, M. (2009) 'Limits and Possibilities of Middle Class Associations as Urban Collective Actors', Economic and Political Weekly, 44(26/27), pp. 368-76. 
Kaur, Ravinder (2001) 'Aspects of Poverty in a Metropolis: a Case Study of an Affluent slum', in Ravinder Singh Sandhu, Sarup Singh Minhas \& Jasmeet Sandhu (eds.), Sustainable Human Settlements, Jaipur: Rawat Publications, pp. 209-23

Kaur, Ravinder (2006) 'Migrating for Work: Rewriting Gender Relations', in Sadhna Arya and Anupama Roy (eds.), Poverty, Gender and Migration, New Delhi: Sage, pp. 192-213.

Kothari, R. (1990) Politics and the People: In Search of a Humane India, London \& New Delhi: Aspect Publications.

Krishna Menon, A.G. (2000) 'The Contemporary Architecture of Delhi: The role of the State as Middleman', in Véronique Dupont, Emma Tarlo \& Denis Vidal (eds.), Delhi: Urban Space and Human Destinies, New Delhi: Manohar Publishers \& Distributors, pp. 143-156.

Kundu, Debolina (2011) 'Elite Capture in Participatory Urban Governance', Economic and Political Weekly, 46(10), pp. 23-5.

Laxman, R.K. (2002) The Best of Laxman: The Common Man Tackles Corruption, New Delhi: Penguin Books.

Legg, Stephen (2006a) ‘Governmentality, Congestion and Calculation in Colonial Delhi', Social \& Cultural Geography, 7(5), pp. 709-29.

Legg, Stephen (2006b) 'Post-Colonial Developmentalities: From the Delhi Improvement Trust to the Delhi Development Authority', in Saraswati Raju, M. Satish Kumar \& Stuart Corbridge (eds.), Colonial and Post-Colonial Geographies of India, New Delhi: Sage Publications, pp. 182-204.

Legg, Stephen (2007) Spaces of Colonialism: Delhi's Urban Governmentalities, Oxford: Blackwell Publishing.

Low, S.M. (1996) 'Spatializing Culture: The Social Production and Social Construction of Public Space in Costa Rica’, American Ethnologist, 23(4), pp. 861-79.

Low, Setha M. (2001) 'The Edge and the Center: Gated Communities and the Discourse of Urban Fear', American Anthropologist, 103(1), pp. 45-58.

Mehra, Diya (2009) 'Campaigning Against its Eviction: Local Trade in New 'World-Class' Delhi' in Melissa Butcher and Selvaraj Velayutham (eds.), Dissent and Cultural Resistance in Asia's Cities, Oxford: Routledge, pp. 148-67.

Mitra, Arup (2003) Occupational Choices, Networks and Transfers: An Exegesis Based on Micro Data from Delhi Slums, New Delhi: Manohar Publishers \& Distributors.

Mosse, David. (1994) 'Authority, Gender and Knowledge: Theoretical Reflections on the Practice of Participatory Rural Appraisal', Development and Change, 25(3), pp. 497-526.

Nash, June (2005) 'Introduction: Social Movements and Global Processes', in June Nash (ed.), Social Movements: An Anthropological Reader, Oxford: Blackwell Publishing, pp. 1-27.

Omvedt, Gail (1993) Reinventing Revolution: New Social Movements and the Socialist Tradition in India, Armonk N.Y.: M.E. Sharpe.

Peck, Lucy (2005) Delhi, a Thousand Years of Building, New Delhi: The Lotus Collection.

Pottier, Johan (1998) 'Towards an Ethnography of Participatory Rural Appraisal and Research', in Ralph Grillo and Roderick Stirrat (eds.), Discourses of Development: Anthropological Perspectives, Oxford: Berg, pp. 203-28.

Robins, Steven; Cornwall, Andrea; von Lieres, Bettina (2008) 'Rethinking 'Citizenship', in the Postcolony', Third World Quarterly, 29(6), pp. 1069-86. 
Rodman, Margaret C. (1992) 'Empowering Place: Multilocality and Multivocality', American Anthropologist, 94(3), pp. 640-56.

Roy, Ananya; Ong, Aihwa (eds.) (2011) Worlding cities: Asian Experiments and the Art of being Global, Chichester: Wiley-Blackwell.

Sethi, Aman (2006) ‘Unwanted Citizens', Frontline, 23 (1), 14-17 January.

Shah, Alpa; Pettigrew, Judith (eds.) (2012) Windows into a Revolution: Ethnographies of Maoism in India and Nepal, New Delhi: Orient Blackswan.

Shiva Kumar, A. K.; Government of NCT of Delhi (2006) Delhi Human Development Report 2006: Partnerships for Progress, New Delhi: Oxford University Press.

Singh, V.B. (2000) ‘Political Profile of Delhi and Support Bases of Parties: an Analysis', in Véronique Dupont, Emma Tarlo, and Denis Vidal (eds.), Delhi: Urban Space and Human Destinies, New Delhi: Manohar Publishers \& Distributors, pp. 205-25.

Srivastava, Sanjay (2009) 'Urban Spaces, Disney-Divinity and Moral Middle Classes', Economic and Political Weekly, 44(26/27), pp. 338-45.

Tawa Lama-Rewal, Stephanie (2007) 'Neighbourhood Associations and Local Democracy: Delhi Municipal Elections 2007', Economic and Political Weekly, 42(47) pp. 51-60.

Vene Klasen, Lisa; Miller, Valerie; Clark, Cindy; Reilly, Molly (2004) 'Rights-Based Approaches and Beyond: Challenges of Linking Rights and Participation', Institute of Development Studies Working Paper 235.

Verma, Gita (2002) Slumming India: a Chronicle of Slums and their Saviours, New Delhi: Penguin Books.

Visvanathan, Shiv (2008) 'The Necessity of Corruption', Seminar No. 590, URL: http://www.indiaseminar.com/2008/590/590_shiv_visvanathan.htm.

Waldrop, Anne (2004) 'Gating and Class Relations: the Case of a New Delhi 'Colony”, City \& Society, 16(2), pp. 93-116.

Webb, Martin (2010) 'Success Stories: Rhetoric, Authenticity, and the Right to Information Movement in North India', Contemporary South Asia, 18(3), pp. 293-304.

Webb, Martin (2012) 'Activating Citizens, Remaking Brokerage: Transparency Activism, Ethical Scenes, and the Urban Poor in Delhi', PoLAR: Political and Legal Anthropology Review, 35(2), pp. 206-22.

Webb, Martin (2013) 'Disciplining the everyday state and society? Anti-corruption and Right to Information Activism in Delhi', Contributions to Indian Sociology, 47(3), pp. 363-93.

Zérah, Marie-Helene (2007) 'Middle Class Neighbourhood Associations as Political Players in Mumbai', Economic and Political Weekly, 42(47), pp. 61-8.

\section{ABSTRACTS}

Through ethnography of activist organisations promoting transparency, accountability and active citizenship, and comprising coalitions of the city's middle classes and urban poor, this article explores the spaces in which activists from different social backgrounds meet and carry out their work. By locating the positions of meeting rooms, offices and activists' homes in urban space, I open up a view of the everyday practices of grassroots governance initiatives aimed at 
producing shared citizenship. I show how Delhi's social and spatial segregation requires that the working through of a politics of shared citizenship must necessarily take place outside, or in between, the city's zones of exclusivity and exclusion. I also show how activist initiatives partially incorporate the urban poor into new regimes of governance and accountability by mirroring everyday processes of leadership and mediation.

INDEX

Keywords: activism, urban space, Delhi, citizenship, governance.

\section{AUTHOR}

\section{MARTIN WEBB}

Lecturer in Anthropology, Goldsmiths College, University of London 